\title{
More Advice for Engaging Students Online
}

\author{
Kimberly Eddleston (Northeastern University)
}

KEYWORDS: Teaching Methods, crisis management.

Now that you (successfully) moved your course online, are you looking for activities and techniques to incorporate? This follow-up article to "Professors Share Tips for Moving Online" (https://familybusiness.org/content/Professors-sharebest-practices-for-the-online-classroom) offers several ideas from FamilyBusiness.org board members that are easy to implement. Links to some free resources (videos, cases) are also shared. Our board wishes all of you good health!

\section{Suggestions for student activities Video Interviews}

"I have students record video interviews with authors of articles. Recording a 10-15 minute video interview with one of the authors of an article they found interesting is a quick thing that provides high value to the class. No preparation is obviously required from the author, and interesting discussions spontaneously emerge. Moreover, this activity is quite effective in connecting discussion to particular aspects covered in the course. This activity also works well with video interviews of family business leaders and entrepreneurs." --Massimo Bau, Jönköping University

\section{Case Presentations With Polls}

"Case studies are still a must. But, to keep the students engaged and not have 50 case analyses, I assign different cases to the students in my class (I have 50 students, divided in 10 groups of 5 students each). Each case solution is then presented by the two groups on Zoom. The rest of the class addresses questions to the presenters. Then, using the poll function of Zoom each student votes for the best solution. The students that did not present the case are also required to write a short reflection (600 words) with a case solution." -- Tommaso Minola and Lucio Cassia, University of Bergamo

Create a Debate on the Class Discussion Board
"I create opinion discussion questions that require a "yes" or "no" vote and ask students to defend their position with two reasons. One example that has worked very well is: 'Family business successors must have outside experience to be successful in leading the family company.'

I have also used the following quite well: 'Every family business is unique and works to define the relationship between their family and their business. Families can choose whether or not to pass ownership through the generations exclusively through bloodlines or to share ownership with spouses who have married into the family. On the class discussion board, post your view on whether in-laws should receive shares of the family company. If yes, how will families overcome this risk of extending ownership? If no, how will the family overcome the disadvantages of concentrating ownership exclusively in blood relatives?'" -- Sherri Noxel, Enterprising Generations (formerly of Oregon State University)

\section{Share the News}

"I always think students should be reading and talking about the news. I require students to share family business news and articles of interest that relate to the course content on our discussion board. For example, the current circumstances have created an ideal situation to talk about values in decision making."

-- Carol Wittmeyer, St. Bonaventure University

\section{Advice for increasing student engagement}

"Be interactive. The great thing about the online environment is that you can combine a lot of approaches to learning - videos, short documents, selfassessments, blogs - which can make learning really fun." -- Isabel Botero, University of Louisville

"Some educational platforms already include online quizzes. If you do not have access to them, you can use
Copyright @ 2020 The Authors. Entrepreneur \& Innovation Exchange is published at EIX.org. This is an open access article under the terms of the Creative Commons Attribution-NoDerivs License, which permits use and distribution in any medium, provided the original work is properly cited and no modifications or adaptations are made. View EIX.org Authorship Terms at https://eix.org/terms
FamilyBusiness 
freely available ones such as Kahoot, (https://kahoot.com) where you can register as an educator. All students will be able to participate in the quizzes you create and share their insights and answers wherever they are." -- Rania Labaki, EDHEC Family Business Center

"Engage in 15 minutes a day to send cool links and news to students. It suffices to look at your email inbox folder or Linkedin thread: you'll get so many inputs they'll love. After all, they want to be entertained too." -- Tommaso Minola and Lucio Cassia, University of Bergamo

"Create opportunities for interaction and motivate the students to be proactive. I ask very frequently students to share their feedback and motivate them to play a proactive role in the lecture by asking questions, by referring to and commenting on contemporary events related to family business issues (e.g., the potential effects of covin-19 on family business strategies), and also by giving them a $5 \%$ score depending on their participations. Stimulating discussions and "humanizing" the classroom is quite important to keep high the students' commitment and ability to e-learn." -- Alfredo De Massis, Free University of Bozen-Bolzano

"In terms of moving online, I recommend colleagues in entrepreneurship and family business create a Google doc for their department to share best practices of what works and what doesn't for them in this process. This is a continuously edited document that everyone can contribute to, ask questions, etc." -- Whitney Peake, Western Kentucky University

\section{Free resources, ready to use}

"FamilyBusiness.org has an array of resources that are ready to use - videos, 'translation' articles, cases, and exercises.

This article

(https://familybusiness.org/content/family-busines s-professors-resources-for-online-learning) lists many of our best resources that work well online. -- Franz Kellermanns, University of North Carolina Charlotte

"The Artisan Entrepreneurship Project offers free training modules, videos, self-assessments and cases, with the aim to enhance entrepreneurial skills and competencies within agro-tourism and artisan family businesses. The project was funded by the EU Erasmus+. The team, which included multiple scholars and universities across Europe, was led by Panikkos Poutziouris. The program is available in English, French, Italian, Greek, and Portuguese in a web-based platform. It was a pleasure to be a part of this important project, which I hope others find useful and enjoy using! -- Prof. Salvatore Tomaselli, Università degli Studi di Palermo 